\title{
Matched comparison of p53, c-erb B2 and bcl-2 markers in breast cancer tissue and fine needle aspiration biopsy materials
}

\section{Meme karsinomlarında p53, c-erb B2 ve bcl-2 işaretleyicilerinin doku kesitinde ve ince iğne aspirasyon biyopsi materyallerinde karşılaştırmalı değerlendirilmesi}

\author{
Esin Cengiz Boduroğlu, Sultan Çiğdem Irkkan, Tulu Ayata Kebat
}

Dr. A. Y. Ankara Onkoloji Eğitim Ve Araştırma Hastanesi, Patoloji Kliniğii, Ankara, Türkiye

Dergiye Ulaşma Tarihi:28/08/2014 Dergiye Kabul Tarihi:08/01/2015 Doi: 10.5505/aot.2014.48568

\section{ÖZET}

Amaç: Meme karsinomlarında ince iğne aspirasyon biyopsisi tanının ve bir kısım prognostik parametrenin belirlenmesi için cerrahi biyopsinin yerine uygun bir alternatif olarak kabul edilmektedir. Bu çalışmada ardişık gönderilen 100 mastektomi spesmeninde tümörden ince iğne aspirasyon biyopsi yöntemi ile elde edilen örnekte p53, bcl-2, c-erb B2 immün boyamaları yapılmış ve doku boyamaları ile karşılaştırmalı olarak incelenmiştir. Yöntemler: Doku fiksasyonu ve takibi aşamaları sonucu antijenitede gelişebilecek değişikliklerin önlenebilmesi için doku kesitleri frozen yöntemle çalıșılmıştır.

Bulgular: Frozen kesitlerde yeterlilik \%98.67, ince iğne aspirasyon biyopsisi materyallerinde yeterlilik \%99 olarak bulunmuştur. Her üç antikorun doku ve ince iğne aspirasyon biyopsisi boyanmaları arasında istatistiksel anlamlı ilişki bulunmuştur ( $\mathrm{p}<0.05)$. Sitolojik materyalde p53 duyarlılığ düşük (\%50) olmakla birlikte özgüllük yüksek bulunmuştur (\%92.3). Diğer antikorlar için hem duyarlılık hem de özgüllük yüksek bulunmuştur (sırasıyla bcl-2 için \%89.2 ve \%92.5, c-erb B2 için \%84.1 ve \%89.6).

Sonuç: Bu bulgular 1şı̆̆ında meme karsinomlarında p53, bcl-2, c-erb B2 sitolojik materyalde güvenle kullanılabilir ancak p53 boyamasında duyarlılık düşük olduğu için yalancı negatif sonuç verebilir.

Anahtar Kelimeler: Meme kanseri; Sitoloji; p53; c-erb B2; bcl-2

\begin{abstract}
Objective: Fine needle aspiration (FNA) is accepted to be an appropriate alternative to surgical biopsy both for diagnosis and definition of some prognostic parameters in breast cancer. In this study, p53, bcl-2 and c-erb B2 immunoreactivity of 100 consecutive cases that both FNA and mastectomy performed were compared.

Methods: Frozen samples of tissue were used in the study in order to eliminate the effects of the tissue processing.

Results: The adequacy of samples was $98.67 \%$ for the tissue sampling and $99 \%$ for the FNA materials. There were statistically significant relationship between tissue and cytologic material for each of the three markers $(\mathrm{p}<0.05)$. The sensitivity of p53 in cytologic material was quite low $(50 \%)$ but sensitivity was high $(92.3 \%)$. The sensitivity and the specifity for both bcl-2 and c-erb B2 were high (sensitivity 89.2\%, 84.1\% and specifity $92.5 \%, 89.6 \%$, respectively).

Conclusion: Fine needle aspiration biopsy material could be used safely to determine p53, bcl-2, c-erb B2 in breast cancer, but it has to be kept in mind that the p53 specifity is quite low and p53 staining in cytologic material could lead to false negative results.
\end{abstract}

Key words: Breast cancer; Cytology; p53; c-erb B2; bcl-2

\section{Giriş}

Günümüz tıp uygulamalarında maliyet hesapları önem kazanmıştır. Pahalı ve uzun zaman alabilecek tanı yöntemlerini, doğruluğu ve güvenilirliği gösterilmiş daha kısa zamanda sonuçlanan ve daha ucuza mal olan yöntemlerle değiştirmek oldukça cazip görünmektedir. Meme karsinomlarında ince iğne aspirasyon biyopsisinin (İ̇AB) tanısal amaçla insizyonel veya eksizyonel biyopsinin yerine geçebilen uygun ucuz ve kolay bir alternatif olduğu kabul edilmektedir (1-3). Doğruluğu \%90'lara ulaşmaktadır $\quad(4,5)$. Ancak meme karsinomlarında artık tedaviye başlarken yalnızca tanının belirlenmiş olması 
yetmemektedir. Kanser tanıs1 hücresel antijenlerin ve reseptörlerin gösterilmesi ile desteklenebilmekte ve böylece tedavinin şekillendirilmesi mümkün olmaktadır (6). Biyopsi materyallerinde hormon reseptörleri ile birlikte karsinogenezde rolü olduğuna inanılan ve prognostik önemleri netleşmemiş olsa da prognostik parametreler ile yakın ilişkisi bulunan bazı işaretleyicilerin ve prediktif belirleyicilerin de çalışılması gerekebilmektedir (7-10). Bu noktadan yola çıkarak çalışmamızda meme karsinomlarında sıklıkla araştırma konusu olan p53, bcl-2, cerb B2 işaretleyicileri (11-16) immünhistokimya (İHK) boyama yöntemi kullanılarak, frozen kesit ve İIAB materyallerinde çalışılmış ve boyanma sonuçları karşılaştırılmıştır. $\mathrm{Bu}$ çalışmada seçilen antikorlar hücre içinde değişik yerleşime sahip olup, yerleşim yerinin sitolojik materyalde zorluğa neden olup olmadığının da değerlendirilmesi amaçlanmıştır.

\section{Gereç ve Yöntem}

$\mathrm{Bu}$ çalışmaya Patoloji Laboratuvarına Eylül 1997-Aralık 1999 tarihleri arasında ardışık gönderilen, meme karsinomu nedeniyle mastektomi uygulanmış 100 adet olguya ait, rezidü tümör içeren mastektomi materyali dahil edilmiştir.

Olgulara ait cinsiyet, yaş, fizik muayene ve laboratuvar bulgularını içeren klinik bilgiler hastane dosyalarından ve patoloji raporlarından alınmıştır. Laboratuvarımıza gelen rezidü tümör içeren mastektomi spesmenlerindeki tümöral dokulardan saklanmak üzere frozen kesitleri alınmış, İİAB yapılıp, yayma preparatlar hazırlanmıştır. Frozen kesitler fikse edilmeden, yayma preparatlar ise $-20^{\circ} \mathrm{C}$ 'de saf asetonda fikse edilerek derin dondurucuda $-20^{\circ} \mathrm{C}$ de boyamaların yapılacağı zamana kadar saklanmıştır.

\section{Immünohistokimyasal boyama yöntemi}

Dondurucudan çıkarılan frozen kesitler ve yayma preparatlar oda sicaklığında 10 dakika saf aseton ve ardından 10 dakika tris tampon (pH: 7.6) çözeltide bekletilmiştir. Protein bloğu takiben, anti- bcl2 antikoru (monoklonal, mouse 1/1000, Biogenex, USA), anti-p53 antikoru (mono- clonal, mouse, clone DO-7 konsantre, 1/3000, DAKO Glostrup DENMARK) ve anti-c-erb B2 antikoru (Monoclonal, mouse, clone CD11 konsantre, 1/250, Biogenex, USA uygulanmış, buzdolabında $+4{ }^{\circ} \mathrm{C}$ en az 18 saat inkübasyona bırakılmıştır. Yirmi dakika biotinlenmiş multilink (Biogenex, USA) sekonder antikorunu takiben $20 \mathrm{dk}$ alkalen fosfataz konjuge streptovidin label (Biogenex, USA) uygulanmıştır. Her aşamada ara yıkamalar tris tampon ile yapılmıştır. New fuchsin substrat (Biogenex, USA) damlatılarak 40 dakika bekletilmiş ve distile su ile yıkanıp, Mayer's hematoksilen ile zit boyama yapılmıştır.

İHK boyama sonuçları 1şık mikroskobunda incelenmiştir. Bcl-2 için dokudaki lenfositler internal pozitif kontrol olarak kullanılmıştır. Tümör hücrelerindeki sitoplazmik boyanma pozitif olarak kabul edilmiştir. P53 ile yalnızca nükleer boyanma pozitif olarak kabul edilirken, c-erb B2 ile membranöz boyanma pozitif olarak değerlendirilmiştir. c-erb B2 ile sitoplazmik boyanmalar pozitiflik olarak kabul edilmemiştir. Ancak bütün materyallerde antikor dilüsyonu ile giderilemeyen, protein blok kullanılmasina ve $+4{ }^{\circ} \mathrm{C}$ de uzun inkübasyona rağmen myoepitelyal boyanma izlenmişstir. Boyamalar yapılırken p53 ve cerb B2 pozitif olduğu bilinen meme karsinomu örnekleri pozitif kontrol ve antikor aşaması tampon solüsyon ile değiştirilerek negatif kontrol olarak kullanılmıştır.

İHK boyamalarda pozitiflik oranlar1 semi-kantitatif olarak yüzde değerleri belirlenerek ve $\% 25^{\prime}$ den az, \%26-75, $\% 75$ 'den fazla şeklinde gruplara ayrılarak derecelendirilmiştir (11).

Yayma preparatlar değerlendirilirken, preperatta en az 3 epitelyal hücre kümesinin görülmesi durumunda örnekleme yeterli olarak kabul edilmiştir (12). Üç hücre kümesi görülemeyen olgularda yedek yayma preparatlarına ikinci kez boyama uygulanmış, ikinci boyamada da en az üç hücre kümesi görülmeyenler yetersiz örnekleme olarak kabul edilmiştir.

\section{Verilerin istatistiksel değerlendirmesi}

Sonuçlar "SPSS for windows" paket programında değerlendirilmiştir. Tüm ista- 
tistiklerde en küçük anlamlılık sınırı 0.05 olarak kabul edilmiştir. Değerlendirmede bağımlı grup oranlarının karşılaştırmasında "Mc Nemar" testi kullanılmıştır.

Duyarlılık ve özgüllük hesaplamaları aşağıda verilen formüller kullanılarak yapılmıştır:

Duyarlılık = gerçek pozitiflik x 100/ örnek say1s1

Özgüllük = yalanc1 pozitiflik x 100/ örnek sayis1

\section{Sonuçlar}

Çalışma grubu 100 olgudan oluşmaktadır. Olgulara ait tümörlerin histopatolojik tipleri Tablo 1'de verilmektedir. Tümörlü dokulara ait frozen kesitlerin hazırlanmasinda yetersiz örnek sayısının 300 örnek içinde 4 adet (\%1.33), yayma preparatlarda ise 300 örnek içinde 3 adet (\%1) olduğu izlenmektedir (Tablo 2).

Tablo 1. Çalışma grubunda tümörlerin histopatolojik tipleri

\begin{tabular}{lll}
\hline Histopatolojik tip & $\begin{array}{l}\text { Olgu } \\
\text { sayısı }\end{array}$ & $\%$ \\
\hline İnvaziv duktal karsinom & 81 & 81 \\
İnvaziv lobüler karsinom & 10 & 10 \\
İnvaziv duktal ve invaziv & 3 & 3 \\
lobüler karsinom & & \\
İnvaziv papiller karsinom & 1 & 1 \\
İnvaziv duktal ve müsinöz & 2 & 2 \\
karsinom & & \\
Metaplastik karsinom & 3 & 3 \\
\hline
\end{tabular}

Tümör frozen kesitleri ve yayma preparatlarına uygulanan $\mathrm{p} 53, \mathrm{bcl}-2$ ve c-erb B2 İHK boyamaların sonuçlarının değerlendirmesi Tablo 2'de görülmektedir

Tümör dokularına uygulanan bcl 2, p53 ve c-erb B2 İHK boyanmalarının frozen kesitler ile yayma preperatlada karş1laştırılması aşağıda sırayla verilmektedir. Tümöre ait bcl-2 İHK boyama sonuçları Tablo 3 'te izlenmektedir.

İİAB'de bcl-2 boyamasinın duyarl1lığ1 \%89.2, özgüllük \%92.5 olarak bulunmuştur. Tümör dokularına ait frozen kesit ve yayma preparatlarda izlenen p53 İHK boyanmasının karşılaştırılması Tablo 4'de verilmektedir. İİAB' de p53 boyamasının duyarlılığ1 \%50, özgüllük \%92.3 olarak bulunmuştur. Tümör dokularına ait frozen kesit ve yayma preparatlarda izlenen c-erb B2 İHK boyanması karşılaştırma sonuçları Tablo 5'de verilmektedir. İİAB'de c-erb B2 boyamasının duyarlılığ1 \%84.1, özgüllük \%89.6 olarak bulunmuş̧tur.

\section{Tartışma}

IİAB'de yeterlilik araştırılması, tanımlanması gereken önemli bir noktadır. Alınan örneklerin dokuları temsil edip etmediğinin belirlenmesi gerekir. Çalışmamızda materyal örnekleme yeterliliği incelendiğinde hem frozen kesitlerde hem yayma preparatlarda yetersiz örneklemelerin olduğu gözlenmiştir. Kesitler için toplam 300 örnek içinde 4 adet (\%1.33), yayma preparatlar için yine toplam 300 örnek içinde 3 adet (\%1) örnek yeterlilik kriterlerini sağlayamamıştır (Tablo 2). Yeterlilik kriterlerinin farklı belirlenmesi yetersiz örnek sayısını yakından ilgilendirmektedir. Meme İ̈AB lerinde yetersiz örnek miktarı \%20.2-34 olabilmektedir. Kline ve ark.'nın çalışmasında yayma preparatları yeterli olarak değerlendirilmesi için minimum gerekli epitelyal küme sayısı 6'dan bire indirildiğinde yetersiz preparat oranı \%13.7'ye düşmüştür (17).

Çalışma grubuna İHK yöntemle p53, bcl-2 ve c-erb B2 antikorlar1 hem frozen kesitlere hem yayma preparatlara uygulanmıştır. Doku takibinin getireceği antijen maskelenmesini ortadan kaldırmak amaciyla yayma materyalinin kıyaslanmasında frozen kesitlerin kullanılması uygun görülmüştür.

Tümöral dokulara ait frozen kesitlerde p53 pozitif olgu sayıs1 28 (\%28) iken yayma preparatlarda p53 pozitif olgu say1s1 14'e (\%14) düşmüştür (Tablo 2).Yetersiz materyal miktarı aynı kalırken kesitte pozitif olan 
Tablo 2. Tümör frozen kesitleri ve yayma preparatlarına uygulanan p53, bcl-2 ve c-erb B2 immünhistokimyasal boyamaların sonuçları.

\begin{tabular}{|c|c|c|c|c|c|}
\hline & & \multicolumn{2}{|c|}{ Frozen kesit } & \multicolumn{2}{|c|}{ Yayma preparatlar } \\
\hline & & say1 & yüzde & say1 & yüzde \\
\hline \multirow[t]{3}{*}{ P53 } & yetersiz materyal & 1 & 1 & 1 & 1 \\
\hline & negatif boyanma & 71 & 71 & 85 & 85 \\
\hline & pozitif boyanma & 28 & 28 & 14 & 14 \\
\hline \multirow[t]{3}{*}{ Bcl-2 } & yetersiz materyal & - & - & - & - \\
\hline & negatif boyanma & 17 & 17 & 20 & 20 \\
\hline & pozitif boyanma & 83 & 83 & 80 & 80 \\
\hline \multirow[t]{3}{*}{ c-erb B2 } & yetersiz materyal & 3 & 3 & 2 & 2 \\
\hline & negatif boyanma & 14 & 14 & 20 & 20 \\
\hline & pozitif boyanma & 83 & 83 & 78 & 78 \\
\hline \multirow[t]{3}{*}{ TOPLAM } & yetersiz materyal & 4 & 1.33 & 3 & 1.00 \\
\hline & negatif boyanma & 102 & 34.00 & 125 & 41.67 \\
\hline & pozitif boyanma & 194 & 64.67 & 172 & 57.33 \\
\hline
\end{tabular}

Tablo 3. Tümör dokularına ait frozen kesit ve yayma preparatlarda izlenen bcl-2 immünhistokimyasal boyanmasının karşılaştırılması.

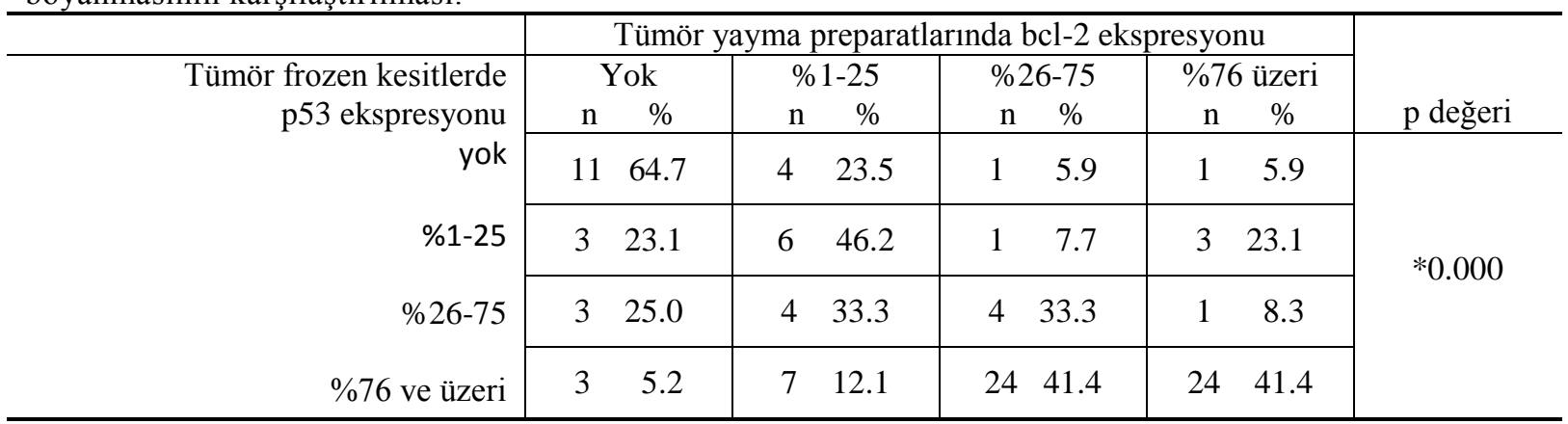

*: istatistiksel olarak anlamlı (Mc Nemar testi)

Tablo 4. Tümör dokularına ait frozen kesit ve yayma preparatlarda izlenen p53 immünhistokimyasal boyanmasının karşılaştırılması.

\begin{tabular}{|c|c|c|c|c|c|}
\hline \multirow{4}{*}{$\begin{array}{r}\text { Tümör frozen kesitlerde } \\
\text { p53 ekspresyonu } \\
\text { yok }\end{array}$} & \multicolumn{4}{|c|}{ Tümör yayma preparatlarında p53 ekspresyonu } & \multirow[b]{3}{*}{ p değeri } \\
\hline & Yok & $\% 1-25$ & $\% 26-75$ & $\% 76$ üzeri & \\
\hline & $\%$ & $\%$ & $\mathrm{n} \quad \%$ & $\%$ & \\
\hline & 6998.6 & $\begin{array}{ll}0 & 0.0\end{array}$ & 11.4 & $0 \quad 0.0$ & \multirow{4}{*}{$* 0.000$} \\
\hline$\% 1-25$ & 1280.0 & 320.0 & $\begin{array}{ll}0 & 0.0\end{array}$ & $\begin{array}{ll}0 & 0.0\end{array}$ & \\
\hline$\% 26-75$ & 111.1 & 111.1 & 777.8 & $\begin{array}{ll}0 & 0.0\end{array}$ & \\
\hline$\% 76$ ve üzeri & 375.0 & 00.0 & $\begin{array}{ll}0 & 0.0\end{array}$ & 125.0 & \\
\hline
\end{tabular}

*: istatistiksel olarak anlamlı (Mc Nemar testi)

olguların \%50'sinin yayma preparatlarda negatif olarak bulunması dikkat çekicidir. Ancak istatistiksel değerlendirmede kesitlerdeki boyanma ile sitolojik materyaldeki boyanma arasında istatistiksel olarak anlamlı bir ilişki saptanmıştır ( $p=0.000)$ (Tablo 4). Değişik çalışmalarda frozen kesitlerde p53 pozitifliği \%38.5 ile \%52 arasında değişmektedir $(18,19)$. Çalışmamızdaki pozitiflik 
oranı bu değerlere göre düşüktür. Literatürde p53 pozitifliğinin değişik antikorların kullanılması ve laboratuvar farklılıklarına bağlı olarak değişik oranlarda görüldüğü belirtilmektedir
(20, 21). Sitolojik materyalde p53 İHK boyamalarında pozitiflik oran $1 \% 13$ ile $\% 57$

Tablo 5. Tümör dokularına ait frozen kesit ve yayma preparatlarda izlenen p53 immünhistokimyasal boyanmasının karşılaştırılması.

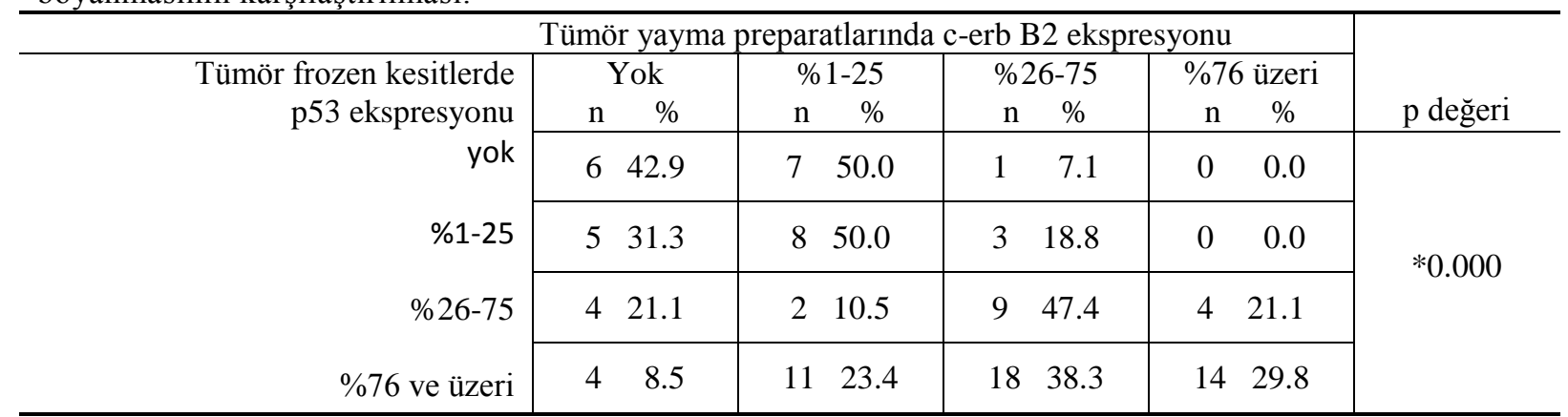

*: istatistiksel olarak anlamlı (Mc Nemar testi)

arasında bildirilmektedir $(22,23)$. Çalıșmamızda elde ettiğimiz \%14'lük pozitiflik literatür ile uyumlu görünmektedir. Ancak İ̇AB materyallerinde frozen kesitlere göre pozitiflik oranının düşmüş olması nedeniyle sitolojik materyalde p53 boyanmasinın duyarlılı̆̆ (sensitivite) \%50, özgüllüğü (spesifisite) \%92.3 olarak bulunmuştur. Çalışma grubumuzda frozen kesitlerde p53 pozitif olan olgularda boyanmanin siklıkla \%1-25 arası hücrede olduğu dikkati çekmektedir yani p53 pozitifliği yaygın olarak saptanmamıştır (Tablo 4). İIAB de doku örneklerine göre daha az hücre elde edilir, p53 boyamalarında zaten yaygin olmayan pozitif hücrelerin daha da seyrelip örneklere rastlamamış olma olasılığı bu sonucu doğurmuş olabilir.

Hori ve ark.'nın frozen kesitlerde bcl-2 boyaması yaptıkları çalıșmalarında \%80.8 olgunun pozitif olduğu gözlenmektedir (24). Parafine gömülü dokulardan elde edilen boyamalarda pozitiflik frozen kesitlerdeki gibi olabileceği gibi daha düşük de olabilmektedir $(25,26)$. Sitolojik materyalde bcl-2 pozitifliği $\% 65$ olarak bildirilmektedir (27). Çalışmamızda yayma preparatlarda bcl-2'nin literatüre göre yüksek bulunması örneklerin operasyon yapıldıktan sonra çok çabuk hazırlanıp hemen $20^{\circ} \mathrm{C}$ aseton ile fikse edilmesine bağli olabilir.
Dokuların oda sıcaklığında beklemesinin bcl-2 overekspresyonunu azalttığı bilinmektedir. Çalışmamızda tümöral dokuda frozen kesitler ve yayma preparatlardaki bcl-2 overekspresyonu arasinda istatistiksel öneme sahip bir ilişki saptanmıştır ( $\mathrm{p}=0.000$ ) (Tablo $3)$. Böylece sitolojik materyalde izlenen bcl-2 boyamasının frozen kesitlerdeki ile paralel olduğu söylenebilir. İIAB'nin duyarlılığı bcl-2 boyamas1 için \%89.2, özgüllüğü ise $\% 92.5$ olarak bulunmuştur. Bu bulgu ile de İIAB'de bcl-2 İHK boyamasının güvenilir sonuçlar verdiği söylenebilir.

Tümöral dokulara yapılan c-erb B2 İHK boyamalarında frozen kesitlerde 83 (\%83) olgu pozitif boyanma gösterirken, yayma preparatlarda 78 (\%78) olgu pozitif boyanma göstermektedir. Meme kanserlerinde c-erb B2 overekspresyonu $\% 11$ ile $\% 42$ arasinda değişen oranlarda bildirilmektedir (28-30). Troncone ve ark.'nın çalışmalarında frozen kesitlerde c-erb B2 pozitifliğini $\% 42$, İ̇AB materyalinde pozitifliği \%48 olarak bildirmektedirler (31). Çalışmamızda c-erb B2 overekspresyonunun yüksek çıkmasının bir nedeni boyamanın frozen kesitlere yapılmış olması, bir diğer nedeni de çalışma grubunun kötü prognostik parametrelere sahip olan olguları yüksek oranda içermesi olabilir. Çalışmamızda tümöral dokuda frozen kesitler ve yayma preparatlardaki c-erb B2 overekspresyonu 
arasında istatistiksel öneme sahip bir ilişki saptanmıştır $(\mathrm{p}=0.000) \quad($ Tablo 5). Böylece sitolojik materyalde izlenen c-erbB-2 boyamasının frozen kesitlerdeki ile kısmen paralel olduğu söylenebilir. İİAB'nin duyarlılığ1 c-erb B2 boyaması için \%84.1, özgüllüğü ise $\% 89.6$ olarak bulunmuștur.

Literatürde meme İ̇AB'lerinde tan1 amaçlı yapılan çalışmalarda duyarlılık ve özgüllüğün yüksek olduğu bildirilmektedir (32). Palombini ve ark.'nın 1956 olgu içeren çalışmalarında meme kitlelerinde yapılan İİAB'nin tanısal duyarlılığı \%95.7, özgüllüğü \% 89.6 olarak bildirilmektedir (33). İIAB'lerde duyarlılık (sensitivite) değişik faktörlerden etkilenmektedir; 1) örneğin yeterliliği, 2) preparatın iyi hazırlanması, 3) boyanın başarısı (12). Çalışmamızda tümöral dokudan yapılan İİA örneklemelerindeki p53, bcl-2 ve c-erb B2 İHK boyanmalarını değerlendirdiğimizde şu sonuçları elde etmekteyiz; yayma preperatlarında P53 ekspresyonuna bakıld1ğında, frozen preparatlarda pozitif olan olguların önemli bir kısmında yalancı negatif sonuç vermektedir. P53 için sitolojik materyalde duyarlılık düşük olmakla birlikte özgüllük yüksektir yani yalanc1 pozitif oran1 tatmin edici oranda düşüktür. Aynı değerlendirmeyi bcl-2 işaretleyicisi için yaptığımızda sitolojik materyalde hem yalanc1 negatif hem de yalancı pozitif sonuçları az olduğunu dolayısı ile bcl-2 İHK boyamasının rahatlıkla sitolojik materyalde kullanılabileceğini ve güvenilir olduğunu görmekteyiz. Son işaretleyici c-erb B2'de bcl-2'de olduğu gibi yüksek duyarlılık ve özgüllüğe sahip bulunmuştur ve güvenle IİAB materyallerinde kullanılabilir. C-erb B2'nin meme karsinomlarında tedavi seçimlerini etkilemesi nedeniyle İ̇B materyalinde güvenilir sonuçlar vermesinin ayrı bir önemi olduğuna inaniyoruz.

Elde ettiğimiz bu bulguların 1şığında meme karsinomlarinda p53, bcl-2, c-erb B2 için İIAB materyallerinin kullanılabileceğini düşünüyoruz. Ancak p53 boyamasında özellikle pozitifliğin yaygın olmadığ pozitiflik izlenen) olgularda duyarlılığın düşük olduğu yani yalancı negatif sonuç verebileceği ak1lda tutulmalıdır.

Doku takibi uygulanmadığından frozen kesitlerle sitolojik materyal, antijenitelerini korumaları bakımından birbirleri ile eşdeğer görülebilir. Frozen kesitler ile karş1- laştırıldığında İİAB materyallerinde İHK uygulamas1 meme kanseri taramalarında ucuz ve kolay bir yöntem olarak kullanılabilir. Yeterlilik sorununa karşı hazırlanan preparat sayısının fazla olması etkili olabilir.

\section{Çıkar Çatışması: Yok}

\section{Kaynaklar}

1. Bell DA, Hajdu SI, Urban JA, Gaston JP. Role of aspiration cytology in the diagnosis and management of mammary lesions in office practice. Cancer 1983;51:1182-9

2. Rimm DL, Stastny JF, Rimm EB, et al. Comparison of fine-needle aspiration and open surgical biopsy as methods for obtaining a pathologic diagnosis. Cancer Cytopath 1997;81:51-6

3. Rosenthal DL. Breast lesions diagnosed by fine needle aspiration. Pathol Res Pract 1986;181:6456

4. Gupta RJ, Dowle CS, Simpson JS. The value of needle aspiration cytology of the breast, with an emphasis on the diagnosis of breast disease in young women below the age of 30. Acta Cytologica 1990;34:165-8

5. Norton LW, Davis JR, Wiens JL, et al. Accuracy of aspiration cytology in detecting breast cancer. Surgery 1984;96:806-14

6. Mitteldorf CA, Alves VA, Kanamura CT, Carneiro PC. Immunocytochemistry applied to aspiration biopsy cytology. Acta Cytologica 1999;43:218-26

7. Bozzetti $\mathrm{C}$, Nizzoli $\mathrm{R}$, Naldi $\mathrm{N}$, et al. Bcl-2 expression on fine-needle aspirates from primary breast carcinoma: correlation with other biologic factors. Cancer 1999;87:224-30

8. Fritzsche FR, Bode PK, Moch H, Kristiansen G, Varga Z, Bode B. Determination of the Her-2/neu gene amplification status in cytologic breast cancer specimens using automated silver-enhanced in-situ hybridization (SISH). Am J Surg Pathol 2010;34:1180-5

9. Hemachandran M, Nijhawan R, Joshi K. Cytological grading, apoptosis, and $\mathrm{Bcl}-2$ protein expression in breast cancer. Diagn Cytopathol 2002;26:356-9

10. Park K, Han S. Cytologic Evaluation of p53, Cyclin D1, and Cathepsin D and Their Correlation with Histologic Sections in Primary Breast Carcinoma. J Korean Breast Cancer Soc 2002;5:113-7

11. Slooten HJ, Clahsen PC, Dierendonck JH, et al. Expression of $\mathrm{Bcl}-2$ in node-negative breast cancer is associated with various prognostic factors, but does not predict response to one course of perioperative chemotherapy. $\mathrm{Br} \mathrm{J}$ Cancer 1996;74:78-85

12. Layfield LJ, Mooney EE, Glasgow B, et al. What constitute an adequate smear in fine-needle aspiration cytology of the breast? Cancer Cytopathol 1997;81:16-21

13. Friedrichs K, Gluba S, Eidtmann H, Jonat W. Overexpression of p53 and prognosis in breast cancer. Cancer 1993;72:3641-7 
14. O'Malley FP, Saad Z, Kerkvliet N, et al. The predictive power of semiquantitative immunohistochemical assessment of p53 and cerbB-2 in lymph node-negative breast cancer. Hum Pathol 1996;27:955-63

15. Poller DN, Hutchings CE, Galea $M$, et al. p53 protein expression in human breast cancer: Relationship to expression of epidermal growth factor receptor, c-erbB-2 protein overexpression and oestrogen receptor. Br J Cancer 1992;66:583-8

16. Davidoff AM, Herndon II JE, Glover N,et al. Relation between p53 overexpression and established prognostic factors in breast cancer. Surgery 1991;110:259-64

17. Kline TS. Adequacy and aspirates from the breast: a philosophical approach. Diagn Cytopathol 1995;13:470-2

18. Allred DC, Clark GM, Elledge R, et al. Association of $\mathrm{p} 53$ protein expression with tumor cell proliferation rate and clinical outcome in node-negative breast cancer. J Natl Cancer Inst 1993;85:200-6

19. Poller DN, Hutchings CE, Galea $M$, et al. p53 protein expression in human breast cancer: Relationship to expression of epidermal growth factor receptor, c-erbB-2 protein overexpression and oestrogen receptor. Br J Cancer 1992;66:583-8

20. Fisher CJ, Gillett CE, Vojtesek B, et al. Problems with p53 immunohistological staining: the effect of fixation and variation in the methods of evaluation. Br J Cancer 1994;69:26-31

21. Horne GM, Anderson JJ, Tiniakos DG, et al. P53 protein as a prognostic indicator in breast carcinoma: a comparison of four antibodies for immunohistochemistry. Br J Cancer 1996;73:29-35

22. Elledge RM, Allred DC. The p53 tumor supressor gene in breast cancer. Breast Cancer Research and Treatment 1994;32:39-47

23. Ioakim-Liossi A, Markopoulos C, Karakitsos P, et al. p53 protein expression in benign and malignant breast lesions. Acta Cytol 1998;42:918-22
24. Hori M, Nogami T, Itabashi M, et al. Expression of bcl-2 in human breast cancer: Correlation between hormone receptor status, protein accumulation and DNA strand breaks associated with apoptosis. Pathology International 1997;47:757-76

25. Zhang GJ , Kimijima I, Abe R, et al. Correlation between the expression of apoptosis-related bcl-2 and p53 oncoproteins and the carcinogesis and progression of breast carcinomas. Clin Cancer Res 1997;3:2329-35

26. Zhang G, Kimijima İ, Tsuchiya A, Abe R. The role of bcl-2 expression in breast carcinomas. Oncology Reports 1998;5:1211-6

27. Troncone G, Zeppa P, Vetrani A, et al. Bcl-2 protein in breast cancer cells obtained by fine needle aspiration (FNA). Cytopathology 1995;6:219-25

28. Albanell J, Bellmunt J, Molina R, et al. Nodenegative breast cancers with p53 (-) /HER2-neu (-) status may identify women with very good prognosis. Anticancer Res 1996;16:1027-32

29. Toikkanen S, Helin H, Isola J et al. Prognostic significance of HER2 oncoprotein expression in breast cancer: a 30-year follow-up. J Clin Oncol 1992;10:1044-8

30. Slamon D.J., Godolphin W, Jones LA, et al. Studies of the HER2/neu proto-oncogene in human breast and ovarian cancer. Science 1989; 244: 707712

31. Troncone G, Panico L, Vetrani A, et al. c-erbB-2 expression in FNAB smears and matched surgical specimens of breast cancer. Diagn Cytopatho 1996; $14: 135-9$

32. Rimm DL, Stastny JF, Rimm EB, et al. Comparison of fine-needle aspiration and open surgical biopsy as methods for obtaining a pathologic diagnosis. Cancer Cytopath 1997;81:51-6

33. Palombini L, Fulciniti F, Vetrani A, et al. Fineneedle aspiration biopsies of breast masses. Cancer 1988;61:2273-7 